\title{
Torsion of the hydatid of Morgagni in a teenage girl
}

\author{
Ottavio Adorisio @,${ }^{1}$ Francesca Diomedi Camassei, ${ }^{2}$ Francesco De Peppo ${ }^{1}$
}

${ }^{1}$ Pediatric Surgey, Bambino Gesu Pediatric Hospital, Roma, Italy Department of Laboratories, Pathology Unit, Bambino Gesu Pediatric Hospital, Roma, Italy

\section{Correspondence to}

Dr Ottavio Adorisio;

odomenico.adorisio@opbg.net

Accepted 16 February 2022

\section{DESCRIPTION}

A teenage girl comes to our emergency department for a 2-month history of intermittent right lower quadrant (RLQ) abdominal pain, which worsened in the last 24 hours. She had nausea but neither fever nor vomiting. Blood tests were normal: white blood cells $9800 \mathrm{~mm}^{3}$, red blood cells 493, platelets 220 , haemoglobin $13.7 \mathrm{~g} / \mathrm{dL}$ and C-reactive protein $<0.5 \mathrm{mg} / \mathrm{dL}$. The abdominal ultrasound showed a cystic lesion of $27 \mathrm{~mm}$ in size with a single-chambered, located in the RLQ with normal appendix and no ascites (figure 1A). Due to the suspicion of the mesenteric cyst, an abdominal MRI was performed. The MRI confirmed the presence of the $12 \times 16 \times 11 \mathrm{~mm}$ cystic lesion, between the upper part of the uterus and bladder, inside the omentum with the final diagnosis of a mesothelial cyst (figure 1B). A laparoscopy was performed showing a $10 \mathrm{~mm}$ necrotic cyst, guessed in the omentum, with a thin twisted pedicle arising from the right fallopian tube (figure 1C). The pedicle was transected, and the cyst was removed from the umbilical optical port (figure 1D). The patient was discharged 2 days after the procedure. The postoperative course was uneventful. Pathological examination gave the diagnosis of hydatids of Morgagni (figure 1E-F).

The most common surgical cause of acute RLQ in children is acute appendicitis. Other frequent causes of RLQ abdominal pain in women are ovarian

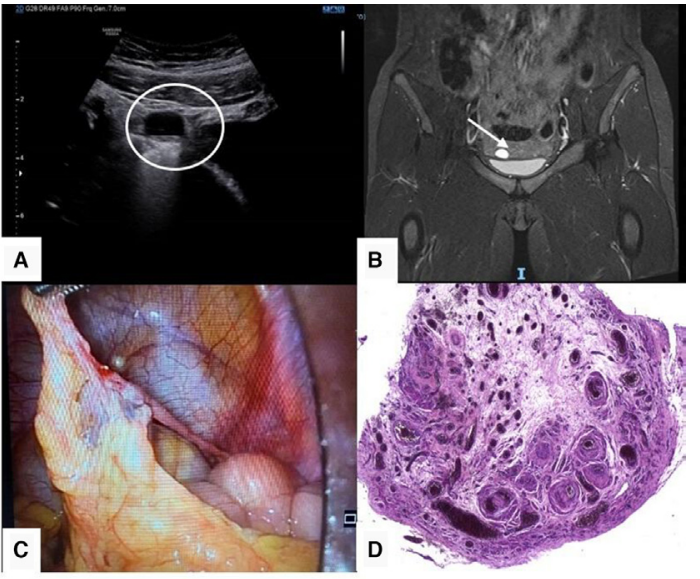

Figure 1 (A) Ultrasound showing cystic lesion inside the omentum. (B) MRI showing the presence of the $12 \times 16 \times 11 \mathrm{~mm}$ cystic lesion, between the upper part of the uterus and bladder, inside the omentum. (C) Intraoperative picture showing the hydatid of Morgagni, located inside the omentum, with a twisted pedicle arising from the right fallopian tube. (D) Histology of the cyst showing cyst wall lined by ciliated columnar epithelial cells.

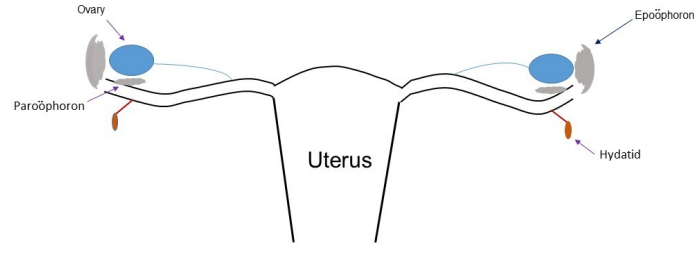

Figure 2 Line diagram of the normal anatomy.

torsion and torsion of other structures involving the fallopian tube or Wolffian duct remnants. Torsion involving the hydatids of Morgagni among girls is rarely reported in the literature. ${ }^{1}$

The hydatid of Morgagni was first described in 1790 by Morgagni. ${ }^{1}$ These small structures are embryonal, pedunculated remnants of Wolffian duct usually located in the terminal part of the fimbria (figure 2). ${ }^{2}$ Typically, the hydatid of Morgagni is a small oval or spherical structure that rarely exceeds $1-2 \mathrm{~cm}$ in diameter. ${ }^{3}$ Torsion in women is very rare and, in most cases, these lesions are discovered incidentally during surgical or laparoscopic procedures performed for other reasons and usually have no clinical significance. ${ }^{4}$ When the diameter is greater than $4 \mathrm{~cm}$ the ultrasound is often diagnostic but in the case of lesions less than $2 \mathrm{~cm}$ the exact diagnosis may be difficult. In previous reports, the patients were operated on for acute appendicitis and the definitive diagnosis was obtained only during the laparotomy or laparoscopy, such as in our case, where the preoperative diagnosis was mesothelial cyst. ${ }^{14}$ Dilatation and torsion of the Wolffian duct remnants are frequently seen in adult women due to the secretory activity of the tubal-type epithelium after or during the pregnancy but very rare in paediatric

\section{Patient's perspective}

I am very happy about the care received by my daughter. I hope that the publication of this article will help other doctors and patients to better recognise and treat this condition.

\section{Learning points}

- Torsion of the hydatids of Morgagni is rare and should be included in the differential diagnosis in young women with acute abdominal pain.

- The pelvic organs should be examined in these post-menarchal patients especially in the presence of normal inflammatory markers.

- Correct diagnosis may avoid unnecessary surgery. 
patients. ${ }^{5}$ In conclusion, it is very important for the paediatric surgeon and paediatrician to be aware of this condition as a cause of RLQ pain. The clinical course is often self-limiting, and the treatment may be conservative based on antibiotic and antiinflammatory drug administration such as described for male patients, avoiding unnecessary surgical exploration and related anaesthesiological procedures. Surgery should be reserved only in case of associated adnexal torsion.

Contributors OA designed the study; OA and FDP performed the procedure; FDC provided the pictures; OA wrote the manuscript. All authors read and approved the final manuscript.

Funding The authors have not declared a specific grant for this research from any funding agency in the public, commercial or not-for-profit sectors.

Competing interests None declared.

Patient consent for publication Consent obtained from parent(s)/guardian(s).

Provenance and peer review Not commissioned; externally peer reviewed.
Case reports provide a valuable learning resource for the scientific community and can indicate areas of interest for future research. They should not be used in isolation to guide treatment choices or public health policy.

\section{ORCID iD}

Ottavio Adorisio http://orcid.org/0000-0002-3727-3366

\section{REFERENCES}

1 Muolokwu E, Sanchez J, Bercaw JL, et al. The incidence and surgical management of paratubal cysts in a pediatric and adolescent population. J Pediatr Surg 2011;46:2161-3.

2 Muthucumaru M, Yahya Z, Ferguson P, et al. Torsion of hydatids of Morgagni in premenarchal adolescent girls--a case report and review of literature. J Pediatr Surg 2011;46:e13-15.

3 Vlahakis-Miliaras E, Miliaras D, Koutsoumis G, et al. Paratubal cysts in young females as an incidental finding in laparotomies performed for right lower quadrant abdominal pain. Pediatr Surg Int 1998;13:141-2.

4 Wittich AC. Hydatid of Morgagni with torsion diagnosed during cesarean delivery. A case report. J Reprod Med 2002:47:680-2.

5 Perlman S, Hertweck P, Fallat ME. Paratubal and tubal abnormalities. Semin Pediatr Surg 2005;14:124-34.

Copyright 2022 BMJ Publishing Group. All rights reserved. For permission to reuse any of this content visit

https://www.bmj.com/company/products-services/rights-and-licensing/permissions/

BMJ Case Report Fellows may re-use this article for personal use and teaching without any further permission.

Become a Fellow of BMJ Case Reports today and you can:

- Submit as many cases as you like

- Enjoy fast sympathetic peer review and rapid publication of accepted articles

- Access all the published articles

Re-use any of the published material for personal use and teaching without further permission

Customer Service

If you have any further queries about your subscription, please contact our customer services team on +44 (0) 2071111105 or via email at support@bmj.com.

Visit casereports.bmj.com for more articles like this and to become a Fellow 